Pamiętnik Literacki 2020, 4, s. 83-89

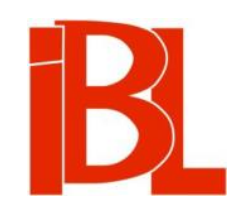

\title{
Refleksje historyka literatury wobec zawieszonej edycji krytycznej „Pism wszystkich" Bolesława Prusa
}

Dorota Samborska-Kukuć 


\section{REFLEKSJE HISTORYKA LITERATURY WOBEC ZAWIESZONEJ EDYCJI KRYTYCZNEJ „PISM WSZYSTKICH” BOLESŁAWA PRUSA}

Naród, który przestaje dbać o zachowanie swojej tradycji, narażony jest na utratę pamięci i tożsamości. Ta sentencjonalna myśl, reprodukowana i konfigurowana po wielekroć przez historyków, filozofów kultury, nawet polityków, oddaje obawy i niepokoje przed rozmyciem rodzimej tradycji. Panteon tej tradycji tworzy - obok innych świadectw - literatura. Do powinności historyków literatury należy dbałość o pielęgnowanie i popularyzowanie dziedzictwa kulturowego, a jednym $z$ przejawów tej kultywacji jest edytowanie dzieł zasługujących na rewaloryzację, dzieł utrwalających przeszłość w jej niewygasłej żywotności, zachowującej wartości nieprzemijające, konstytuujące to, co dla narodu ważne, niekiedy instruktywne, to, co stanowi skarbiec pamiątek. Tak postępują Niemcy, Francuzi, Brytyjczycy etc.; przygotowywane $z$ pietyzmem edycje zbiorowe nie tylko literatów pierwszorzędnych, ale i twórców drugiego planu to potężna dzisiaj i stale doposażana biblioteka tradycji kulturowej tych nacji, ich prestiż i poczucie narodowych wspólnot. To zabezpieczanie pamięci i ocalanie jej dla potomnych. Szczególną rolę w tym ciągu wydań odgrywają te, które określa się mianem „editio maior”, odnawiane jako reedycje lub kolejne opracowania zastanego materiału wedle aktualnych zasad, norm i typografii. Sa one wzbogacane o merytoryczne wstępy, uwzględniają najnowszy stan badań, recepcję dzieł autora, metodologie, odnotowuja zazwyczaj pełną bibliografię oraz stosują nowoczesny aparat przypisowy. Takie publikacje stanowią fundament dla prac analityczno-interpretacyjnych; badacz nie powinien sięgać po wydania pomniejsze, jak wybory, edycje pozbawione eksplikacji, etc., toteż troska o ich edytorską stronę jest niezbędna, konieczna.

Kiedy w roku 2014 pod patronatem Towarzystwa Literackiego im. Adama Mickiewicza, ze środków Ministerstwa Nauki i Szkolnictwa Wyższego w ramach Narodowego Programu Rozwoju Humanistyki, ukazał się inicjalny tom Pism wszystkich Bolesława Prusa, obejmujący Humoreski, nowele, opowiadania, wydawało się, że realizacja tego ambitnego projektu, angażującego i integrującego pochodzacych z różnych ośrodków naukowych wybitnych znawców, obdarzonych intuicją edytorską i mających za sobą takąż praktykę, oraz ich uczniów, młodych miłośników pisarstwa autora Lalki, zostanie doprowadzona do końca - wszak dotychczas nie posiadamy przecież pełnej edycji krytycznej dorobku twórczego Prusa, a połowiczne wydania są albo pozbawione aparatu krytycznego, albo jest on dziś już anachroniczny, o niedostateczności objaśnień i uzgodnień nie wspominając. Na półkach 
bibliotecznych zalegają wprawdzie edycje przeznaczone głównie dla młodzieży, ale zarówno poziom dołączonych opracowań (jeśli w ogóle takie sa), jak ich strona graficzna czy rodzaj papieru pozostawiają wiele do życzenia, a zważywszy na oczekiwania współczesnego młodego odbiorcy literatury - mało kogo do lektury zachęcają. Nowa edycja, jak wnosić wypadało nie tylko z przedmowy Beaty Obsulewicz, kierowniczki grantu, ale przede wszystkim $\mathrm{z}$ profesjonalnego wykonania, była próbą sił i umiejętności edytorskich nowo powołanego zespołu badawczego i wyzwaniem skłaniającym do eksploracji nie znanych dotąd źródeł. Rekonesans czy choćby tylko reasumpcja archiwaliów to w przypadku rekonstruowania tekstu w aspekcie okoliczności jego powstania, jak i procesu tworzenia zabieg bezcenny. Wspomnieć należy również - suum cuique - o wysiłkach recenzentów, ich wnikliwej, uważnej lekturze i komentarzach, dzięki czemu ostateczny efekt prac mógł osiagnnąć poziom więcej niż satysfakcjonujący.

Niestety, po publikacji tomu 35 (z planowanych finalnie około 70) inicjatywa została zawieszona, wprawiając w konsternację środowisko polonistów.

We wstępie do Pism wszystkich Beata Obsulewicz, odwołując się do opinii Polskiej Akademii Literatury z okresu międzywojennego, która rekomendowała potrzebę wydania całości dzieła Prusa, potrzebę wynikająca nie tylko z celu pragmatycznego, ale i z obowiązku wobec twórców szczególnie dla polskiej kultury znaczących, motywuje pomysł edycji koniecznością przeciwdziałania „zagrożeniom dla humanistyki w życiu społecznym i [...] degradowaniu tych tradycyjnych wartości, które dotychczas podtrzymywały naszą kulturę i tożsamość" ${ }^{1}$, diagnozuje ponadto - widząc w tym jedno $\mathrm{z}$ niebezpieczeństw - kondycję współczesnego czytelnictwa jako groźny stan passé i uzasadnia klarownie misję inicjatywy:

Pora najwyższa, by z myślą o przyszłości zapobiegać zagrożeniom i zarazem zadbać o stworzenie trwałej, a zarazem kompletnej bazy dostępności do wszystkich tekstów jednego z naszych najznakomitszych autorów ${ }^{2}$.

Obsulewicz nakreśla dzieje edycji dzieła Prusa podejmowanych w latach 1881-1904, jeszcze za życia pisarza, oraz późniejszych, na wydaniach zespołu Zygmunta Szweykowskiego skończywszy, wskazując wyraźnie na ich ułamkowy, połowiczny, niepełny zakres oraz fakt, że „żadne z dotychczasowych wydań nie było par excellence krytyczne” ${ }^{3}$. Autorka wstępu definiuje ponadto, czym jest „edycja krytyczna" we współczesnym rozumieniu, $\mathrm{z}$ uwzględnieniem założeń tekstologicznych, m.in. z zachowaniem zgodności tekstu $z$ intencją autora, przy immanentnym uznaniu, że „wola autora” to dziś kontrowersyjne pojęcie, ze śledzeniem w rekonstrukcji wariantywnej procesu powstawania dzieła.

1 B. K. Obsulewicz, Wstęp do „Pism wszystkich”. W: B. Prus, Pisma wszystkie: Humoreski, nowele, opowiadania. T. 1: 1864-1874. Red., wstęp T. Żabski. Oprac. T. Żabski, E. Lu bczyńska-Jeziorna, H. Kubicka, A. Kuniczuk-Trzcinowicz. Warszawa-Lublin 2014, s. 5 (przedruk, z niewielkimi zmianami: O edycji krytycznej „Pism wszystkich” Bolesława Prusa słów kilka. „Wiek XIX” 2015).

2 Ibidem.

3 Ibidem, s. 6. 
Przyglądając się kolejnym tomom Pism wszystkich, które ukazały się dotąd, można stwierdzić, że zamysł podziału na serie $\mathrm{z}$ zastosowaniem dwu kryteriów: gatunkowego i chronologicznego (A: Humoreski, nowele, opowiadania; B: Powieści; C: Kartki z podróży; D: Publicystyka filozoficzno-społeczna i literacka; E: Kroniki, F: Korespondencja, G: Notatki twórcze), jest przejrzysty i porządkujący, co więcej, pozwala na wyeksponowanie zasadniczych typów pisarstwa Prusa, a także sprzyja osadzeniu jego twórczości w kontekstach biograficznym i historyczno-społecznym. Takie spostrzeżenie można uczynić, ponieważ zespół Obsulewicz - jakby przeczuwając niebezpieczeństwo niedokończenia projektu - został zmobilizowany do pracy we wszystkich wymienionych modułach, toteż niemal każdy z nich ma swoje egzemplifikacje: i powieść, i małe formy, i publicystyka, i korespondencja, i notatki twórcze.

Eksplikacje historycznoliterackie poprzedzające poszczególne tomy (oraz dodatkowo powieści) mają wysoki walor poznawczy, metoda krytyki tekstu jest przemyślana i wykonana $\mathrm{z}$ wielką pieczołowitością, a jego modernizacja sfunkcjonalizowana, $\mathrm{z}$ dbałością zarówno o to, by oddawał on język i styl autora, jak i o to, by ten styl i język były zarazem blisko współczesnego czytelnika, świadomego jednak odmienności konwencji komunikacyjnej. Każdy tom zawiera uwagi i objaśnienia historyczne, historycznoliterackie oraz realioznawcze, poszerzające i pogłębiające lekturę; w każdym znajdują się adnotacje edytorskie.

Podkreślić należy, że poddawana temu komentarzowi edycja nie jest wznowieniem wydania Szweykowskiego, które zresztą nie było stricte krytyczne; jej formuła jest innowacyjna, bo taka być dzisiaj musi, zarówno w aspekcie tekstologicznym, jak typograficznym i historycznoliterackim, wykorzystującym najnowsze metodologie naukowe w celu pogłębienia refleksji nad pisarstwem i warsztatem twórczym Prusa. Raczej trudno wyobrazić sobie, by w XXI wieku poważny badacz np. jego publicystyki czynił podstawą swoich analiz (już na etapie kwerendalnym) Kroniki edytowane przez Szweykowskiego czy ich wybory w opracowaniu Stanisława Fity (1987), Józefa Bachórza (1994), Samuela Sandlera i Bartłomieja Szleszyńskiego (2006), ponieważ, mimo ich niezaprzeczalnych walorów, w pierwszym przypadku objaśnienia mają charakter eliptyczny, natomiast pozostałe wydania, choć opracowane wzorowo, z założenia są wybiórcze. Ani zatem historyk, ani ekspert w dziedzinie literatury, ani prasoznawca, zwłaszcza zaś „nieprofesjonalista”, np. dziennikarz, szukający w „encyklopedycznych” Kronikach m.in. informacji o Warszawie epoki postyczniowej, nie zostanie usatysfakcjonowany edycją Szweykowskiego, a tym bardziej - wyborem Bachórza. Toteż dzisiejszy badacz literatury XIX-wiecznej na samo zbudowanie kompletnego korpusu źródłowego będzie musiał poświęcić mnóstwo czasu.

Innym jeszcze wartym zaakcentowania mankamentem wydania Szweykowskiego jest zastosowanie przypisów końcowych (zresztą niemerytorycznych), a nie dolnych, na domiar - nienumerowanych ${ }^{4}$. Taka formuła jest dla wnikliwego badacza, nawykłego dziś do synchronicznego śledzenia tekstu oraz komentarzy wyja-

4 Na tę niedoskonałość edycji Szweykowskiego zwraca uwage E. Sk o r u pa lOdsłony edytorskich zmagań $z$ „Kronikami”. W: E. Skor u pa, G. P. Bą biak, M. Gabryś-Sławiń s ka, „Kroniki tygodniowe" Bolesława Prusa: edytor - recenzent - czytelnik. Lublin 2017, s. 11-12). 
śniających i lokalizacji, sporym utrudnieniem, zmuszającym go do dodatkowych wysiłków poszukiwawczych.

W stosunkowo niedługim okresie od przyznania środków (rok 2012) do opublikowania ostatniego tomu (2019) ukazały się - jak już powiedziano - 24 woluminy (wszystkie w lubelskim wydawnictwie „Episteme”).

W roku 2014 opublikowano Humoreski, nowele, opowiadania (t. 1: 1864-1874) pod redakcją, ze wstępem i w opracowaniu Tadeusza Żabskiego oraz Elżbiety Lubczyńskiej-Jeziornej, Haliny Kubickiej, Agnieszki Kuniczuk-Trzcinowicz, a także tom 1 Notatek twórczych (Notatki ,lubelskie”), które przygotowały do druku Magdalena Kreft i Anna Martuszewska (ze wstępem Martuszewskiej).

Rok 2015 przyniósł kolejne dwa tomy Humoresek [...] (t. 2: 1874-1875; t. 3: 1875-1876), w tym samym co w tomie 1 opracowaniu, oraz dwa tomy Emancypantek, opracowane przez Tomasza Sobieraja i z jego wstępem.

W roku 2016 ukazały się powieści: Dzieci, w opracowaniu i ze wstępem Agaty Grabowskiej-Kuniczuk; Placówka, pod redakcją i w opracowaniu Żabskiego oraz Lubczyńskiej-Jeziornej i Kubickiej, ze wstępem Lubczyńskiej-Jeziornej; dwutomowy zbiór Pałac i rudera, ze wstępem i w opracowaniu Kuniczuk-Trzcinowicz; Dusze $w$ niewoli (wstęp Ewy Paczoskiej, opracowanie tejże badaczki oraz Moniki Nicińskiej); Anielka, która przygotowała do druku i do której wstęp napisała Aneta Mazur, sprawująca $n b$. opiekę merytoryczną nad całą serią tych szkiców powieściowych. W tym samym roku ogłoszono Publicystyke filozoficzno-społeczna i literacka (t. 3: 1889-1900, i t. 4: 1901), w opracowaniu Cezarego Zalewskiego, oraz tom 2 Notatek twórczych (Notatki o kompozycji).

W roku 2017, frekwencyjnie również imponującym, na rynku wydawniczym pojawily się trzy tomy Lalki, w opracowaniu Józefa Bachórza i Beaty Utkowskiej, oraz dalsze dwa tomy Emancypantek, a także 10 tomów Kronikw pięciu woluminach (ze wstępem Tadeusza Budrewicza): wolumin 1, w trzech tomach, zawiera teksty Z „Kolców” i „Gazety Polskiej” (1874) oraz „Niwy” (1875-1876), na wolumin 2, w dwu tomach, składaja się kroniki pisane przez Prusa dla „Kuriera Warszawskiego” i „Ateneum” w latach 1875 i 1876 (oba woluminy opracowała Iwona Węgrzyn), wolumin 3 mieści tomy 8 (1879) i 9 (1880), opracowane przez Ewę Skorupę oraz Joannę Lekan-Mrzewkę, a zawierające teksty z „Kuriera Warszawskiego” i „Gazety Rolniczej", wolumin 4 obejmuje kroniki Prusa publikowane w latach 18811883 (dwa tomy wchodzace w skład tego woluminu opracowała Ewa Skorupa), wolumin 5 - jednotomowy (t. 14: 1885), opracował Tadeusz Budrewicz. W tymże 2017 roku ukazały się również dwa tomy Korespondencji (Listy Bolesława Prusa oraz Listy do Bolesława Prusa), ze wstępem i w opracowaniu Jacka Nowaka, a także tom 3 Notatek twórczych (Kompozycja. Zeszyty 1-3. 1896-1898).

Ostatni tom, który opublikowano w ramach projektu, powieść Przemiany, ze wstępem i w opracowaniu Agnieszki Bąbel i Agaty Grabowskiej-Kuniczuk, datowany jest na rok 2019. Aż tyle, ale w perspektywie braku dalszego ciagu - tylko tyle.

Nie ujrzały światła dziennego ani wybitna powieść Faraon, ani niedokończona Sława, tak ważna w kontekście interpretacyjnym Lalki, ani pozostałych pięć tomów Kronik (t. 6-7 oraz 12-13 i 15), ani tomy 1-2 Publicystyki filozoficzno-społecznej i literackiej, ani Kartki z podróży, ani dalsze tomy opowiadań. Były one (w sumie 
19 tomów) przewidziane do opracowania w kolejnej, drugiej partii grantowego przedsięwzięcia. Wobec zawieszenia prac zapewne nie dojdzie również do skutku realizacja koncepcji edycji cyfrowej (bazy w portalu internetowym), jak też nie zostaną dokonane tak pożądane uzupełnienia bibliograficzne do „prusowskiego” tomu Nowego Korbuta (t. 17, vol. 1), który ukazał się przed 40 laty. Prace nad nowelizacją danych bibliograficznych dotyczących życia i twórczości oraz recepcji dzieła Prusa wydają się naturalną konsekwencją badań prowadzonych nad nimi w ramach edycji (w tym przeglądu archiwaliów i zasobów bibliotecznych).

Nietrudno, patrząc na te dane, dojść do wniosku, że tempo prac było imponujące zwłaszcza że są to dokonania rzetelne i dowodzące kompetencji zespołu - prac wymagających żmudnych i czasochłonnych kwerend, niemalże śledztw detektywistycznych, obligujących do ustalenia nie zawsze oczywistej podstawy wydań, prac dyktujących uzgodnienia dotyczące koniektur i emendacji, wyznaczenia granic ingerencji edytora, założeń modernizacyjnych i typograficznych, jak również - co oczywiste - przymuszających do sformułowania nowych merytorycznych wstępów, sporządzenia not edytorskich, komentarzy, przypisów, indeksu osób, etc. Choć wszystkie tomy mają niezaprzeczalną wartość naukową, na szczególną uwagę zasługuje korespondencja, zwłaszcza ta, która nigdy dotąd nie była publikowana listy do Bolesława Prusa; intymistyka zawsze stanowi istotny kontekst do badan biograficznych i literaturoznawczych, a opracowana tak troskliwie, jak wskazane tomy korespondencji, należy do zasadniczych pozycji, do których będą sięgać badacze, nie tylko prusolodzy. $Z$ całą moca trzeba również zaakcentować ogromny pożytek z Notatek twórczych (Notatek o kompozycji), te niesłychanie trudne nawet do odtworzenia (w manuskrypcie są bowiem liczne skreślenia, nadpisania, tabelaryczne zestawienia, wykresy etc.) unikatowe adnotacje Prusa sa nieprzecenionym źródłem wiedzy o światopoglądzie, pasjach naukowych, toku twórczego myślenia oraz sposobie i stylu pisania autora.

Całość wydanych dzieł spaja utrzymana w jednolitej stylistyce elegancka, minimalistyczna szata graficzna.

Czyżby realizacja zamysłu miała być po raz kolejny niezupełna? Czyżby znów dzieło Bolesława Prusa miał dotknać syndrom fragmentaryczności, niedopełnienia? W tym przypadku jednak, gdy format projektu jest wprost tytaniczny, aktywizujący wysiłek rzeszy polonistów, wykonany już w większej części, a zatem weryfikowalny jako realizujacy przyjęte cele i założenia naukowe oraz wywiązujący się z powinności społecznych, trudno to sobie historykowi literatury wyobrazić, trudno się $\mathrm{z}$ tym pogodzić. Niekontynuowanie zamierzenia wydaje się zaniechaniem niesprawiedliwym i budzącym niepokój.

Zdziwienie historyka literatury zawieszeniem edycji Pism wszystkich Bolesława Prusa wywołuje w szczególności pytanie: ,jeśli nie Prus, to kto?” Trudno byłoby w dziejach naszej literatury przed XX wiekiem znaleźć pisarza o tak przenikliwym umyśle, tak sumiennie i tak odpowiedzialnie wykonującego zawód literata i dziennikarza, stawiającego tak trafne diagnozy - zarówno w prozie artystycznej, jak i w felietonistyce. Poza tym autora niekwestionowanego arcydzieła, jakim jest Lal$k a$, a potwierdzily to nowe badania tekstologiczne Beaty Utkowskiej i na nowo 
napisany przez Józefa Bachórza wstęp do powieści, co powinno w dużej mierze wywołać ciekawość innych literackich robót Prusa - dla kontekstu, dla porównań, jako potrzeby poznania całokształtu jego działalności. Ponówmy pytanie: ,jeśli nie Prus, to kto?” - bo przecież także nie Henryk Sienkiewicz, pierwszy polski noblista, wirtuoz polskiego języka artystycznego, być może najbardziej poczytny polski autor, mający wprawdzie edycję pod redakcją Juliana Krzyżanowskiego, ale niepełną, nie dostosowaną do wymogów współczesności, okaleczoną przez cenzurę PRL-owską, skoro analogiczny do „prusowskiego” projekt legitymizowany przez najwybitniejszych sienkiewiczologów został odrzucony, nie dano mu w ogóle szans na urzeczywistnienie. I zapytajmy po raz trzeci: ,jeśli nie Prus, to kto?”

Może więc nikt, skoro wedle Ministerstwa Nauki i Szkolnictwa Wyższego naukowa edycja tekstu stanowi jedynie 25\% wartości punktowej innej monografii (stosunek 20 do 80), co według osób decyzyjnych degraduje edycję jako publikację mało twórczą, a zatem mało do nauki wnoszącą (!). Mówiąc wprost - podstawowa dawniej działalność filologa uznana została przez decydentów za niewiele znacząca fantazję, wymiernością punktacyjną odstręczająca potencjalnych edytorów. Należy w tym miejscu - jako mocny komentarz - przywołać słowa Grzegorza Bąbiaka, recenzenta jednego z tomów Pism wszystkich:

Nie podlega jakiejkolwiek dyskusji to, że edytorstwo jest jedną z najważniejszych nauk filologicznych, gdyż od tego, w jakiej formie literaturoznawca otrzyma tekst, zależeć będa jego ostateczne wnioski. Edytorstwo jest także sztuka, ponieważ mimo iż ujęte w pewne ogólne zasady i normy (specyficzne dla danych epok), zależy od indywidualnych cech osoby, która stworzyła tekst literacki, i tego, kto podejmuje się jego wydania. Wymaga niekiedy subtelności, ale i kreatywności w odtworzeniu woli autora-artysty ${ }^{5}$.

Warto w kontekście współczesnych dyskursów demaskacyjnych i problematyzowania stereotypizacji narodowych wspomnieć o twórczości Prusa, jako w tym aspekcie istotnej. W jego realistycznym pisarstwie nasza przeszłość nie świeci światłem odbitym w fantazmatach i kliszach, nie ma w niej retuszu, intencjonalnych alternatyw, wyobrażeń, kompensacji. Próżno w niej szukać narodowej megalomanii, ksenofobii, hiperbol patriotycznych. Podejmowana przez autora Lalki próba obiektywizowania Polaków i polskości jest skuteczna: nie wyglądamy tak fotogenicznie jak u wielu innych twórców tego czasu. Czy sprawiła to tendencja autora do percepcji dziennikarskiej, czy rzetelność deskrypcyjna, wynikająca z potrzeby symetrii i kompletności oglądu świata, czy też predyspozycja do wyrażania opinii nie uwikłanych w żadne obce racje i zależności? Zapewne każdy ze wskazanych czynników. W takiej rzeczywistości literackiej zawiera się jakaś forma prawdy, której wartość jest dla nas, Polaków, inspirująca, bo skłania do refleksji i zadumy nad istotą naszej własnej historii oraz dziejowych przemian. Ten realizm jest nam dzisiaj może bardziej niż kiedykolwiek potrzebny, gdy pokolenie młodych częściej sięga (jeśli w ogóle sięga) po lekturę fantasy, odrywającą od rzeczywistości, odsyłającą w świat abstrakcyjnej iluzji. W dobie współczesnego chaosu i relatywności twardy grunt realizmu pozwala porządkować świat, umożliwia podjęcie prób rozumienia mental-

5 G. P. B ą b i a k, Uwagi recenzenta pierwszych tomów „Kronik” Bolesława Prusa. W: jw., s. 155. 
ności przodków, daje szansę, by zdać sobie sprawę, skąd - jako narodowa zbiorowość o niełatwej historii - wyszliśmy i dokąd zdążamy.

Zdziwieniu historyka literatury polskiej ustaniem przedsięwzięcia mającego na celu wydanie Pism wszystkich Bolesława Prusa towarzyszy smutna refleksja o zanikaniu potrzeby pielęgnowania tego, co rodzime, zastępowaniu dziś, w dobie przemian kulturowych o tendencjach unifikacyjnych, ekwiwalentem obcym tego, co powinno być naszą narodową chlubą. Nie dla chwalby, bo Prus daleki był od mityzacji Polaków i polskości, ale dla zabezpieczenia naszej niepowtarzalności, wpisanej w tradycję, zabezpieczenia, jakie winni jesteśmy tym, którzy przyjdą po nas.

\author{
Abstract \\ DOROTA SAMBORSKA-KUKUĆ University of Łódź \\ ORCID: 0000-0002-1943-6694
}

\title{
A LITERARY HISTORIAN'S REFLECTIONS ON THE SUSPENDED CRITICAL EDITION OF BOLESEAW PRUS' "PISMA WSZYSTKIE" ("COLLECTED WORKS")
}

The year 2014 marks the issuing of the first volume of Bolesław Prus' Pisma wszystkie (Collected Works) financed by the National Programme for the Development of Humanities. The publication was planned to amount to 70 volumes and, as signalled in this title, meant to include the writer's whole output. None of the initiatives to publish Prus' work undertaken so far has been completed. The project realised according to the newest (textological, typographic, and literary-historical) principles by the editorial committee, Prus scholars, aimed to offer the edition to various scholars (literary, history, press etc.) as well as to preserve in the model version one of the elements of national heritage-highest artistic quality literature. After the publication of the volume 35, the edition was suspended due to lack of further financing.

The paper discusses the already published volumes, comments on e.g. its editorial shape, composition, level of explicatory introductions, and the importance of the edition for Prus scholars and other researchers of the second part of the $19^{\text {th }}$ century. The discussion is accompanied by a reflection over the condition of the Polish humanities, and especially over the problems caused by neglecting by the changing decision-makers of by its nature long lasting process of petrifying the shape of national identity and preserving the cultural memory. 